\title{
Does thickening save water?
}

\author{
A.J. Vietti Paterson \& Cooke, South Africa \\ J.C.J. Boshoff SRK Consulting, South Africa
}

A. Cope Anglo Platinum Limited, South Africa

\begin{abstract}
A pilot plant paste thickening campaign was conducted at the Anglo Platinum Limited Mogalakwena South Concentrator plant in South Africa in order to determine the water saving capability of paste and thickened tailings (P\&TT) technology. In the process a simple water consumption model was developed for estimating the overall water consumption of the mine. The model indicates that for the Mogalakwena tailings, significant water savings are achieved by discharging thickened tailing directly to the TSF but only at densities where free water release at the TSF is close to zero.
\end{abstract}

\section{Introduction}

South Africa's lack of substantial water resources has been well publicised for decades, however in recent years, a combination of increased urbanisation and industrialisation combined with the commodity boom have reignited concern for the long-term sustainability of the resource.

Within the Bushveld Complex alone, up to 44 mines are either in production, development or in planning (Johnson Matthey, 2008). By assuming an average head feed grade of $3.5 \mathrm{~g} / \mathrm{t}$; stated production targets (for refined equivalent platinum ounces) and an average water consumption of $1.0 \mathrm{~m}^{3} / \mathrm{t}$ of head feed treated a maximum annual total water consumption of $84,850 \mathrm{Ml}$ is estimated for the existing 22 platinum mines operating in the Complex. This figure is likely to double should all the projects be brought to account.

Recent reports indicate that little to no technical high level leadership in respect of water saving strategies are forthcoming and that it is being left to individual mines to come up with solutions (Bennett, 2009). It is perhaps fortunate then that technical innovations, particularly within the last 15 years, such as P\&TT have revolutionised the water recovery and tailings disposal methods available to the mining industry.

\section{$2 \quad$ Paste and thickened tailings}

Although P\&TT has its conceptual roots in the geotechnical field of tailings storage facility (TSF) design, its technical origins were developed within the Alumina industry to reduce the volume of hazardous tailings reporting to the tailings dams (Robinsky, 1999; Getahun et al., 2000). Combining the improved thickening ability with a better understanding of transporting (pumping) and storing the thickened tailings, has allowed the concept to become a practical reality which has been implemented worldwide since the late 1990s (Williams et al., 2008). Within Southern Africa, a number of P\&TT facilities have either been implemented or are in development (Johnson and Vietti, 2003; Williamson, 1997). The main claimed advantages of the technology are amongst others:

- improved water recovery at the plant and hence lower raw water consumption

- improved TSF structural stability since no free water accumulates on the dam

- reduced seepage to groundwater

- improved TSF rehabilitation and reduced closure costs.

Although it is certainly a fact that water consumption can be reduced by thickening and recovering all of the water at the plant, it is also theoretically possible to reduce water consumption by not thickening at all, but by efficiently recovering the water released by the dilute tailings at the TSF and returning it to the plant. Consequently, considerable debate exists as to the actual water saving benefits which can be achieved by P\&TT. 
In an attempt to determine where the water saving benefits lie, a project was initiated by Anglo Platinum Limited which included Paterson \& Cooke and SRK Consulting to determine the water saving benefits by applying P\&TT technology to the Mogalakwena South Concentrator flotation tailings.

\section{$3 \quad$ Paste thickening trials}

A paste thickening pilot plant was designed, built and operated by Paterson \& Cooke and consisted of the following components:

- laboratory/storage container

- slurry holding tank; stirrer and feed pump

- process water holding tank and feed pump

- flocculant make-up and dosing pump

- $300 \mathrm{~mm}$ diameter paste thickener (extendable to $3 \mathrm{~m}$ height) and underflow pump

- dilution tank; stirrer and underflow pump.

Total combined tailings derived from the Platreef ore body, was fed to the paste thickener after which thickened tailings were generated and the thickener operating performance was evaluated; total combined tailings consists of flotation tailings from both the IsaMill ${ }^{\mathrm{TM}}$ grinding mill and conventional ball mill circuits. The rheological properties of the thickened underflow were evaluated for pumping purposes before the flow and drying properties were determined for geotechnical purposes by SRK Consulting. The plant operation and tailings properties are presented in Table 1 and Figure 1.

Table 1 Mogalakwena south concentrator head feed and tailings properties

\begin{tabular}{ll}
\hline Mogalakwena South Concentrator Feed \\
\hline Ore type & Platreef \\
Head feed treated $(\mathrm{t} / \mathrm{h})$ & 575 \\
Specific gravity & 3.2 \\
\hline \multicolumn{2}{l}{ Total Combined Tailings } \\
\hline Pulp density $(\mathrm{kg} /$ litre $)$ & 1.28 \\
Particle size $\mathrm{d}_{50}(\mu \mathrm{m})$ & 27 \\
Average $\mathrm{pH}$ & 9.1 at $21.5^{\circ} \mathrm{C}$ \\
\hline
\end{tabular}




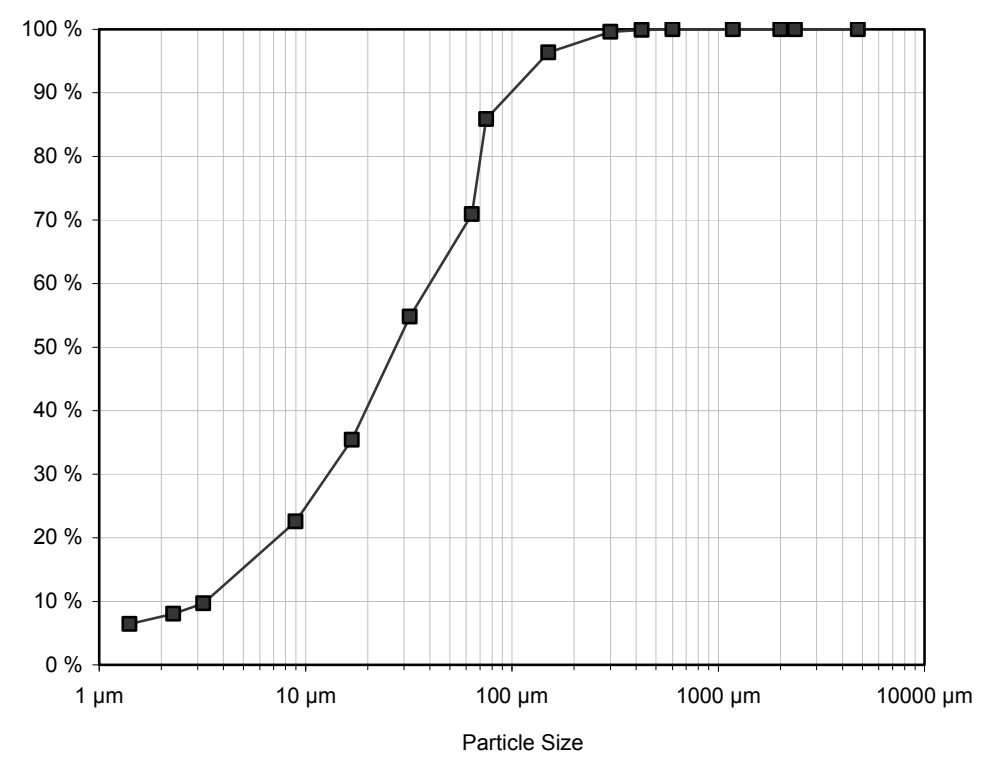

Figure 1 Particle size distribution for the total combined tailings sample

\subsection{Thickening and rheological results}

The thickening performance of the pilot plant paste thickener was demonstrated by plotting the operating point of the thickener (i.e. operating underflow solids concentration) on the sheared yield stress curve for the total combined tailings (Figure 2). The in situ consolidated solids concentration of the tailings in the TSF is also indicated for comparison.

It is apparent that considerable dewatering of the tailings is achieved by paste thickening, allowing the tailings to achieve solids concentrations of $70 \% \mathrm{~m}$ with a fully sheared yield stress of $55 \mathrm{~Pa}$ (Table 2).

Table 2 Paste thickener operating conditions

\begin{tabular}{llllll}
\hline $\begin{array}{l}\text { Operating } \\
\text { Condition }\end{array}$ & $\begin{array}{l}\text { Flocculant } \\
\text { Dose }(\mathbf{g} / \mathbf{t})\end{array}$ & $\begin{array}{l}\text { Solids Flux } \\
\text { Rate }\left(\mathbf{t} / \mathbf{m}^{\mathbf{3}} \cdot \mathbf{h}\right)\end{array}$ & $\begin{array}{l}\text { Fluid Rise } \\
\text { Rate }(\mathbf{m} / \mathbf{h})\end{array}$ & $\begin{array}{l}\text { Underflow Solids } \\
\text { Concentration } \mathbf{( \% )})\end{array}$ & $\begin{array}{l}\text { Sheared Yield } \\
\text { Stress (Pa) }\end{array}$ \\
\hline $\begin{array}{l}\text { Paste } \\
\text { thickener }\end{array}$ & 30 & 0.6 & 5.6 & 70 & 55 \\
\hline
\end{tabular}

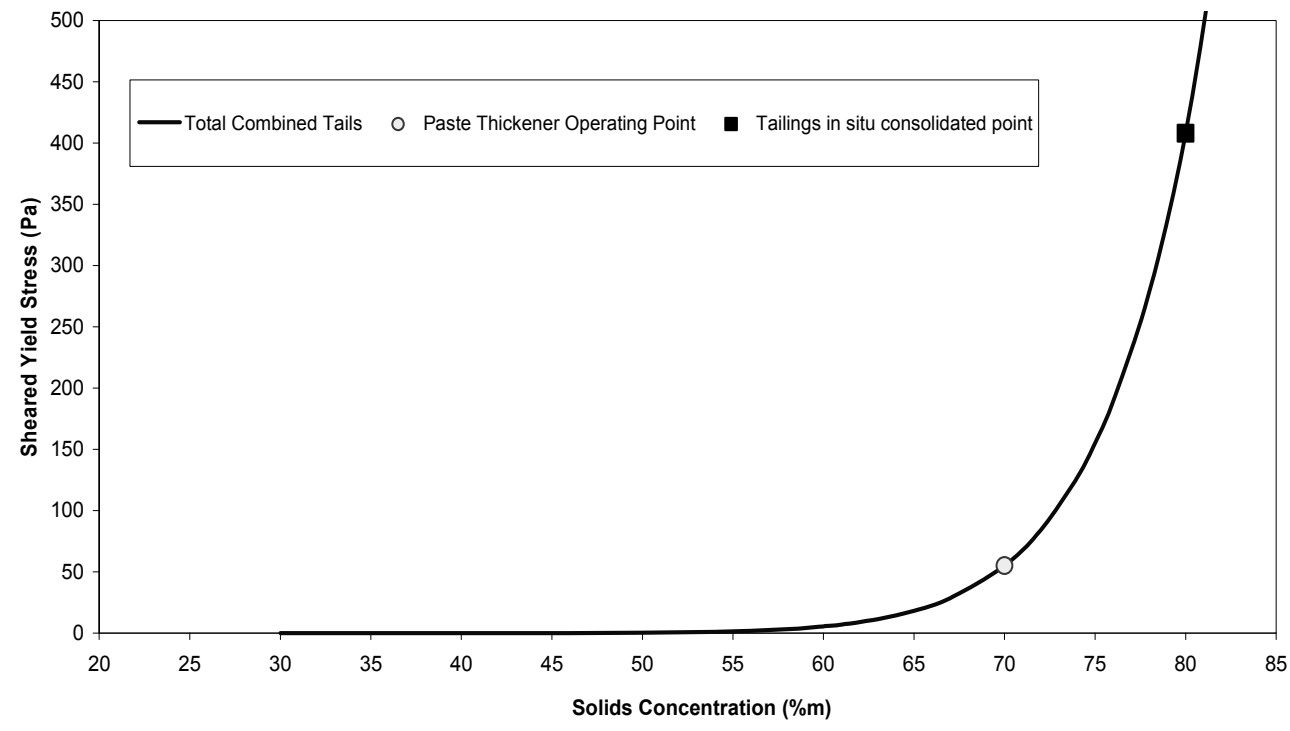

Figure 2 Paste thickener operating performance 


\section{$4 \quad$ Water consumption comparison}

In order to conduct an overall mine water consumption analysis, a steady state model (i.e. once equilibrium conditions have been achieved at the TSF) of the water recovered from both the Mogalakwena South Concentrator Plant and TSF was developed (Figure 3).

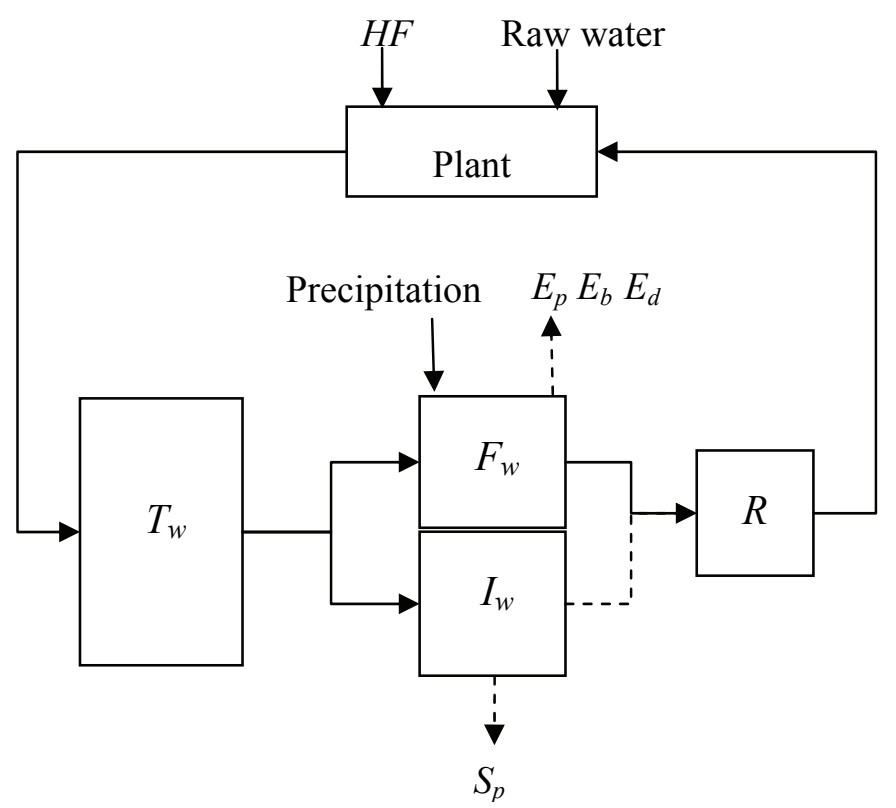

\section{Figure 3 Mine water consumption model}

The model assumes a total TSF footprint area of 110 ha and includes the average yearly precipitation values for the Mokopane area.

The following plant and TSF parameters are defined:

$H F \quad=\quad$ plant head feed $(\mathrm{t} / \mathrm{h})$.

$T_{w}=\quad$ volumetric flow rate of water in the tailings reporting to the TSF $\left(\mathrm{m}^{3} / \mathrm{h}\right)$.

$F_{w}=\quad$ volumetric flow rate of 'Freely Released' water upon discharge at the TSF $\left(\mathrm{m}^{3} / \mathrm{h}\right)$.

$R=$ volumetric flow rate of water recovered to the plant from the return water dam $\left(\mathrm{m}^{3} / \mathrm{h}\right)$.

The water loss parameters are defined as:

$E_{p}=$ evaporation loss at the TSF pond $\left(\mathrm{m}^{3} / \mathrm{h}\right)$.

$E_{b}=$ evaporation loss at the TSF beach (wet and dry areas) $\left(\mathrm{m}^{3} / \mathrm{h}\right)$.

$E_{d} \quad=\quad$ evaporation loss at the return water dam $\left(\mathrm{m}^{3} / \mathrm{h}\right)$.

$S_{p} \quad=\quad$ seepage loss via the TSF base area $\left(\mathrm{m}^{3} / \mathrm{h}\right)$.

$I_{w}=\quad$ volumetric flow rate of interstitial water remaining in the tailings after placement $\left(\mathrm{m}^{3} / \mathrm{h}\right)$.

$I_{f}=\quad$ volumetric flow rate of interstitial water remaining in the tailings after consolidation $\left(\mathrm{m}^{3} / \mathrm{h}\right)$.

The volume of water reporting to the TSF from the plant thickening circuit $\left(T_{w}\right)$ is determined from a mass balance exercise at the plant thickeners. The volume of 'Freely Released' water discharged at the TSF $\left(F_{w}\right)$ is determined by multiplying $T_{w}$ with a water release factor $(f)$ at the placed solids concentration.

The water release factor at any placed solids concentration is determined by constructing a water release curve for the tailings under investigation. Using flocculated tailings, a series of one litre measuring cylinders is set up covering the range of solids concentrations desired. After mixing, the tailings are allowed to settle for 30 minutes after which the volume of supernatant water is recorded. The water release factor is calculated 
as a percentage of total water in the tailings freely released after 30 minutes at a particular slurry solids concentration (Figure 4).

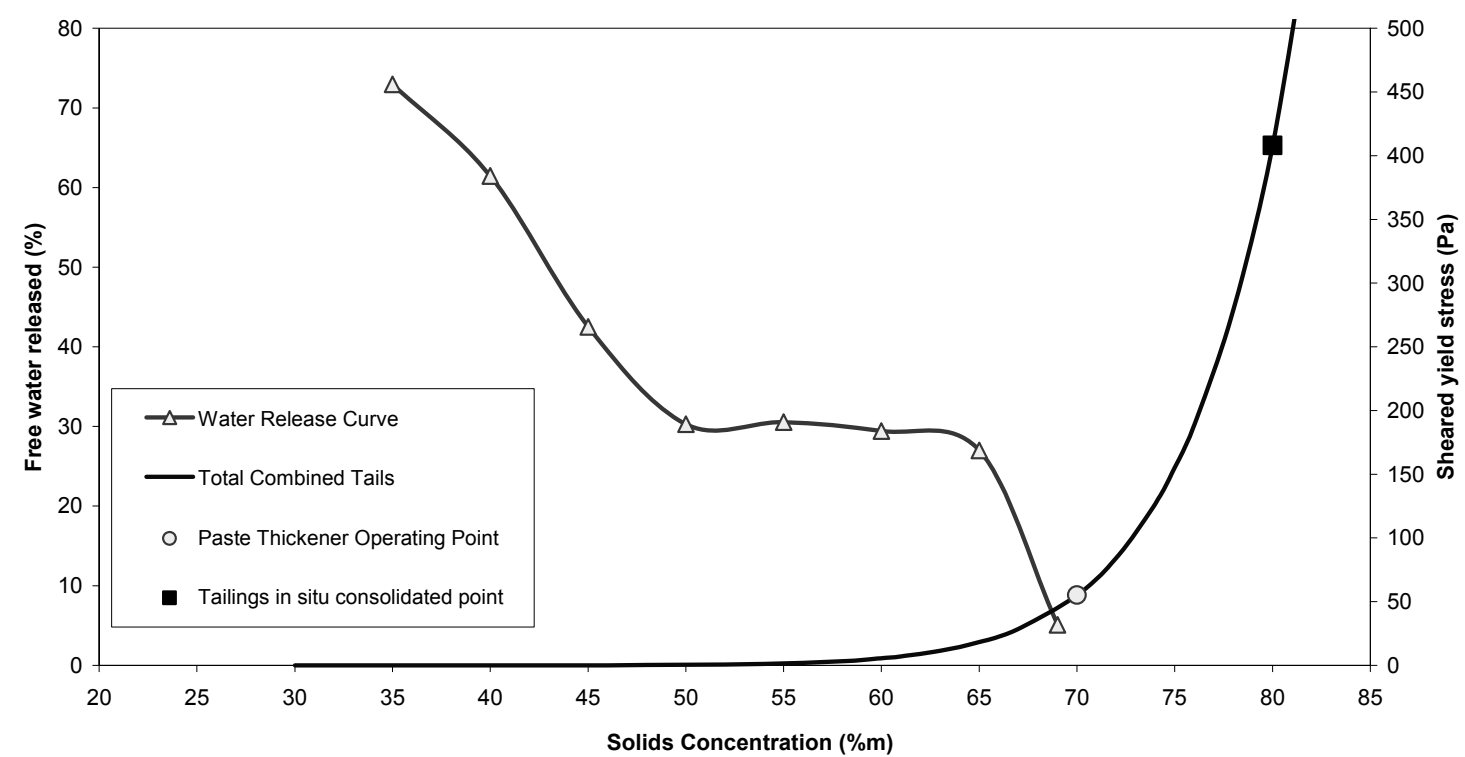

Figure 4 Water release curve for the total combined tailings

The water release curve described in Figure 4 is unique to each tailings material and is dependent on a number of factors such as particle size distribution; particle shape; the presence or not of clay minerals and the tailings chemical conditions.

In order to calculate the evaporative losses, evapotranspiration factors were applied to the various surfaces of the TSF according to the ratios described in Table 3. The return water dam pool area was assumed to vary from 19 to 10 ha at placed slurry solids concentrations ranging from 34 to $60 \% \mathrm{~m}$. No return water dam was assumed for slurry concentrations in excess of $65 \% \mathrm{~m}$.

Table 3 TSF evapotranspiration loss ratios

\begin{tabular}{llll}
\hline $\begin{array}{l}\text { Placed Tailings Solids } \\
\text { Concentration }(\% \mathbf{m})\end{array}$ & \multicolumn{3}{l}{$\begin{array}{l}\text { Percent of Total TSF Footprint } \\
\text { Subject to Evapotranspiration }\end{array}$} \\
\cline { 2 - 4 } & Dry Beach & Wet Beach & Pool \\
\hline Up to 42 & 20 & 65 & 15 \\
42 to 52 & 25 & 65 & 10 \\
52 to 60 & 32 & 65 & 3 \\
60 to 69 & 40 & 60 & 0 \\
\hline
\end{tabular}

Seepage losses were calculated using Darcy's formula in Equation (1), for a tailings material with a permeability $(k)$ of $1 \mathrm{e}-08 \mathrm{~m} / \mathrm{s}$ where, $i$ is the hydraulic head and $A$ is the footprint area of the tailings dam.

$$
Q=k i A
$$

Using the model and the parameters described above, the flow rate of water returned to the plant from the return water dam $(R)$ can be determined in $\mathrm{m}^{3} / \mathrm{h}$ for two tailings consolidation scenarios, i.e. the initial deposited scenario $\left(R_{\text {initial }}\right)$ and the final consolidated scenario $\left(R_{\text {final }}\right)$ where additional water is released from the tailings over time as they consolidate to their final in situ density. The $R_{\text {initial }}$ scenario only accounts for water recoverable after losses due to evaporation. Loss due to tailings lock-up after initial placement $\left(I_{w}\right)$ or seepage $\left(S_{p}\right)$ are ignored.

$$
R_{\text {initial }}=\left(T_{w} \times f\right)-\left(E_{p}+E_{d}+E_{b}\right)
$$


In order to determine the additional water recovered after consolidation has been achieved, the term $\left(I_{f}\right)$ is introduced which describes the volumetric flow rate of water permanently lost to the TSF at the final in situ consolidated density.

$$
R_{\text {final }}=R_{\text {initial }}+\left(I_{w}-I_{f}\right)-S_{p}
$$

Under equilibrium conditions, an estimated mine water consumption $(W C)$ in $\mathrm{m}^{3} / \mathrm{t}$ of head feed treated can then be determined.

$$
W C=\frac{T_{w}-R_{\text {final }}}{H F}
$$

The estimated mine water consumption for the Mogalakwena South Concentrator Plant is presented in Figure 5.

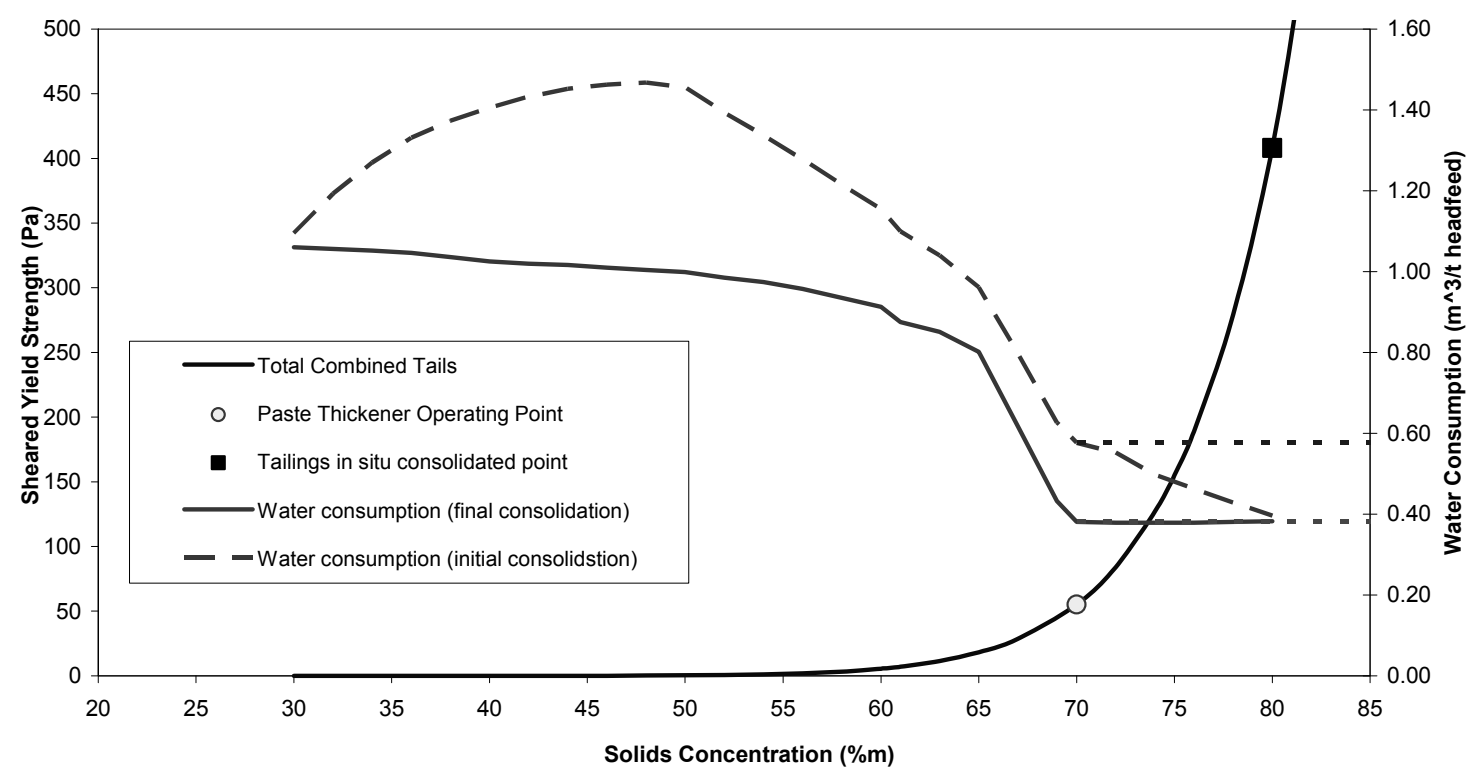

Figure 5 Mogalakwena south concentrator water consumption curve

\section{Conclusion}

This study presents a simple model which provides a methodology for estimating mine water consumption. Under steady state conditions any TSF will contain tailings that are both in the unconsolidated and consolidated state. The model therefore defines a range of water consumption values spanning these consolidated states depending on the density at which the tailings are placed.

Critical to the model's input is the water release curve which is unique to each tailings material as its shape determines the amount of water immediately released at the TSF and available for recovery. The volume of free water released by the total combined tailings varies as a function of placed density at the TSF. At low solids concentrations, a high percentage of free water is released (up to $73 \%$ at tailings solids concentrations of $35 \% \mathrm{~m}$ ). As the solids concentration of the tailings increases towards 50 to $55 \% \mathrm{~m}$, the slurry develops a measurable yield stress (i.e. the gel point of the slurry) and the percentage of free water released decreases leading to an increase in water loss due to interstitial lock-up. Without consolidation of the tailings, maximum water loss appears to be achieved close to the gel point solids concentration. As the tailings are thickened beyond the gel point to approximately $65 \% \mathrm{~m}$, water consumption decreases due to smaller volumes of water reporting to the TSF; smaller evaporative surface areas and a relatively constant water release of $30 \%$ over this range. Thickening beyond $65 \% \mathrm{~m}$, the tailings permeability decreases to such an extent that free water release and hence evaporative losses approach zero.

The difference between the initial and final water consumption curves reflects the recovery of water which has been released from the tailings during consolidation to its final in situ density. The curve reflects the 
steady decrease in water lost to evaporation; seepage and interstitial water due to thickening. From 65 to $70 \% \mathrm{~m}$, there is a rapid decrease in the release of free water resulting in a dramatic improvement in water consumption as pool size and hence evaporation losses are reduced. From $70 \%$ solids onwards, a minimum intrinsic water loss is achieved which reflects the interstitial lock-up and wet beach evaporation losses only. Thickening beyond $70 \% \mathrm{~m}$ results in the recovery of incremental volumes of water which have an insignificant effect on water savings.

Therefore to return to the question posed in the title of this paper, it appears that only by increasing the density of the tailings at placement (i.e. thickening) under steady state conditions saves water. Depositing at low solids concentration does not improve water consumption. It would also appear that the rate at which the tailings are able to consolidate to their final in situ density also plays a significant role in water savings. In this regard, high rates of rise within the TSF particularly if the tailings are placed at solids concentrations near their gel point appear to negatively affect water consumption. If thickening is employed, the lowest water consumptions are achieved by placing the tailings at high underflow solids concentrations where free water release is close to zero. Thickening beyond this point does not contribute to further water savings.

In the final analysis, it would appear that water consumption can be greatly reduced by implementing P\&TT technology within the mining industry and that the technology offers a solution to economic expansion and resource sustainability.

\section{Acknowledgements}

The authors wish to thank the management of the Anglo Platinum Limited and the Mogalakwena South Concentrator Plant for their permission to publish the paper.

\section{References}

Bennett, G. (2009) Water crisis looms for SA platinum belt, viewed 16 September 2009, Mineweb.com

Getahun, H, O’Callaghan, W.B. and Hartney, T. (2000) Experience with thickened red mud tailings (Paste) stacking in tropical and temperate climates and applicability of the technology to other Tailings, 53rd Ann. Conf. of the Canadian Geotechnical Society, Montreal, Canada, pp. 683-690.

Johnson, G. and Vietti, A.J. (2003) The design of a co-thickened tailings disposal system, International Seminar on Paste and Thickened Tailings, Australian Centre for Geomechanics, Perth, Australia.

Johnson Matthey (2008) Platinum Today: Platinum 2008, Internal Publication.

Robinsky, E.I. (1999) Thickened Tailings Disposal in the mining industry, Toronto, Canada.

Williams, M.P.A., Seddon, K.D. and Fitton, T.G. (2008) Surface disposal of Paste and Thickened Tailings - A brief history and current confronting issues, in Proceedings 11th International Seminar on Paste and Thickened Tailings, Australian Centre for Geomechanics, Perth, Australia, pp. 143-164.

Williamson. J.R.G. (1997) The residue waste disposal facility for Iscor's Hillendale Project in KwaZulu Natal, J. S. Afr. Inst. Min Metall., pp. 275-280. 
